\title{
OBJEK SENGKETA TATA USAHA NEGARA
}

\author{
Nama : Jafar Shiddiq \\ Email : Jafarshiddiq789@gmail.com \\ No BP : 2010003600355 \\ Universitas Eka Sakti Padang
}

\section{A. PENDAHULUAN}

Indonesia sebagai suatu negara hukum, memiliki badan peradilan yang merdeka dalam menyelenggarakan kekuasaan kehakiman guna menegakan hukum dan keadilan. Berdasarkan ketentuan Pasal 24 ayat (1) UUD NKRI 1945, yang berbunyi, Kekuasaan kehakiman merupakan kekuasaan yang merdeka untuk menyelenggarakan peradilan guna menegakkan hukum dan keadilan. Kekuasaan Kehakiman dilakukan oleh sebuah Mahkamah Agung dan badan-badan peradilan yang berada di bawahnya dalam lingkungan Peradilan Umum, lingkungan Peradilan Agama, lingkungaan Peradilan Militer, lingkungan Peradilan Tata Usaha Negara, dan oleh sebuah Mahkamah Konstitusi. 5 Tujuan pembentukan dan kedudukan suatu peradilan Tata Usaha Negara (PTUN) dalam suatu negara, terkait dengan falsafah negara yang dianutnya. Negara Kesatuan Republik Indonesia merupakan negara hukum berdasarkan Pancasila dan UUD 1945, Oleh karenanya hak dan kepentingan perseorangan dijunjung tinggi disamping juga hak masyarakatnya. Secara filosofis tujuan 5 Ketentuan Sebagaimana Diatur Dalam Pasal 24 Ayat (1) dan Ayat (2) UUD 1945 Tersebut Diatas, Ditegaskan Kembali Dalam Pasal 1 Dan 2 UndangUndang Nomor 48 Tahun 2009 tentang Kekuasaan Kehakiman. 5 pembentukan peradilan administrasi negara (PTUN) adalah untuk memberikan perlindungan terhadap hak-hak perseorangan dan hak-hak masyarakat, sehingga tercapai keserasian, keseimbangan dan 
keselarasan antara kepentingan perseorangan dengan kepentingan masyarakat atau kepentingan umum. Badan Peradilan Tata Usaha Negara mempunyai wewenang menerima, memeriksa dan mengadili serta menyelesaikan perkara sengketa-sengketa terkait dengan Tata Usaha Negara (TUN), yakni sengketa-sengketa antara orang atau 9 Pasal 47 Undang-Undang Nomor 51 Tahun 2009 tentang Perubahan Kedua Atas UndangUndang Nomor 5 Tahun 1986 tentang Peradilan Tata Usaha Negara. 7 badan hukum perdata dengan badan atau pejabat TUN, di pusat dan daerah, sebagai akibat diterbitkannya keputusan TUN oleh badan atau pejabat TUN yang oleh pencari keadilan dianggap bertentangan dengan peraturan dan merugikan dirinya sebagai perorangan atau badan hukum perdata. Kewenangan peradilan Tata Usaha Negara tersebut, kemudian ditampung dalam penjelasaan umum angka ke 1 Undang-Undang Nomor 5 Tahun 1986 tentang Tata Usaha Negara.10Mangacu pada rumusan pengertian sengketa Tata Usaha Negara dalam Pasal 1 ayat (4) Undang-Undang PTUN, dapat disimpulkan bahwa unsur-unsur sengketa Tata Usaha Negara terdiri dari: a. Subjek yang bersengketa adalah orang atau badan hukum privat di satu pihak dan badan atau pejabat tata usaha negara di lain pihak. b. Objek sengketa TUN, adalah keputusan yang dikeluarkan oleh badan atau pejabat tata usaha negara. Lebih lanjut pada Pasal 53 ayat (1) menyebutkan bahwa seseorang atau badan hukum perdata yang merasa kepentingannya dirugikan oleh suatu Keputusan Tata Usaha Negara dapat mengajukan gugatan tertulis kepada pengadilan yang berwenang yang berisi tuntutan agar keputusan tata usaha negara yang disengketakan itu dinyatakan batal atau tidak sah, dengan atau tanpa disertai tuntutan ganti rugi dan atau rehabilitasi. 


\section{B. PEMBAHASAN}

Sengketa Tata Usaha Negara adalah sengketa yang timbul dalam bidang tata usaha negara yakni antara orang atau badan hukum perdata dengan badan atau pejabat tata usaha negara, baik di pusat maupun di daerah, sebagai akibat dikeluarkannya keputusan tata usaha negara, termasuk sengketa kepegawaian berdasarkan peraturan perundang-undangan yang berlaku sebagaimana dimaksud dalam Pasal 1 angka 10 UU Nomor 51 Tahun 2009 Tentang Peradilan Tata Usaha Negara (UU PTUN).

Dalam penjelasan Pasal 1 angka 4 UU PTUN menyebutkan bahwa istilah sengketa yang dimaksud dalam UU tersebut mempunyai arti sesuai dengan fungsi peradilan TUN, yaitu menilai perbedaan pendapat mengenai penerapan hukum badan atau pejabat TUN dalam mengambil keputusan dan pada dasarnya mengemban kepentingan umum dan masyarakat, tetapi dalam hal perkara tertentu dapat saja keputusan itu dirasa merugikan orang lain sehingga asas hukum tata negara memberi kesempatan bagi pihak yang dirugikan untuk mengajukan gugatan ke pengadilan.

Sengketa tata usaha negara ini berpangkal dari ditetapkannya suatu keputusan TUN oleh badan atau pejabat TUN. Oleh karena itu, pada hakikatnya sengketa tata usaha negara adalah sengketa tentang sah atau tidaknya suatu keputusan TUN yang telah dikeluarkan oleh badan atau pejabat tata usaha negara, atau dengan kata lain dapat ditarik kesimpulan bahwa yang dapat digugat di hadapan pengadilan TUN hanyalah badan atau pejabat TUN, selain itu sengketa yang dapat diadili oleh peradilan tata usaha negara adalah sengketa mengenai sah atau tidaknya suatu keputusan TUN, bukan sengketa mengenai kepentingan hak. 
Untuk menilai mengenai sah atau tidaknya keputusan TUN negara yang dikeluarkan oleh badan atau pejabat TUN yang disengketakan oleh seseorang atau badan hukum perdata merupakan kewenangan peradilan TUN, dan apabila hak-hak seseorang atau badan hukum dirugikan oleh adanya keputusan pejabat TUN maka menurut ketentuan tersebut dapat diajukan ke pengadilan TUN. Untuk mengajukan gugatan ke pengadilan TUN, perlu dipahami dan diketahui dahulu apa yang menjadi objek sengketa yang diperkarakan. Objek sengketa dalam proses mengajukan gugatan ke Pengadilan TUN telah ditentukan dalam Pasal 1 angka 9 UU PTUN yang berbunyi :

“Keputusan Tata Usaha Negara adalah suatu penetapan tertulis yang dikeluarkan oleh badan atau pejabat tata usaha negara yang berdasarkan peraturan perundang-undangan yang berlaku, yang bersifat konkret, individual, dan final, yang menimbulkan akibat hukum bagi seseorang atau badan hukum perdata"

Berdasarkan pengertian tersebut objek sengketa TUN terbagi menjadi 2(dua) yakni objek sengketa yang bersifat positif, dan objek sengketa yang bersifat fiktif, adapun objek sengketa TUN yang berisfat poisitif ialah terdiri dari unsur-unsur sebagai berikut :

1. Penetapan tertulis

Menurut Pasal 1 angka 3 UU PTUN penetapan tertulis dirumuskan sebagai Keputusan TUN

2. Dikeluarkan oleh badan atau pejabat TUN

3. Berisi tindakan Hukum TUN berdasarkan peraturan perundang-undangan

4. Bersifat konkret dan individual, dan

5. Menimbulkan akibat hukum bagi seseorang atau badan hukum 
Kemudian adapun objek sengketa yang bersifat fiktif negatif tersebut diatur dalam ketentuan pasal 3 UU PTUN yang berbunyi :

1. Apabila badan atau pejabat tata usaha negara tidak mengeluarkan keputusan, sedangkan hal itu menjadi kewajibannya, maka hal tersebut disamakan dengan keputusan tata usaha negara.

2. Jika suatu badan atau pejabat tata usaha negara tidak mengeluarkan keputusan yang dimohon. Adapun jangka waktu sebagaimana ditentukan dalam peraturan perundang-undangan dimaksud telah lewat. Maka badan atau pejabat tata usaha negara tersebut dianggap telah menolak mengeluarkan keputusan yang dimaksud. Badan atau pejabat tata usaha negara yang menerima permohonan dianggap telah mengeluarkan keputusan yang berisi penolakan permohonan tersebut apabila tenggang waktu yang ditetapkan telah lewat dan badan atau pejabat tata usaha negara itu bersikap diam, tidak melayani permohonan yang telah diterimanya.

3. Dalam hal peraturan perundang-undangan yang bersangkutan tidak menentukan jangka waktu sebagaimana dimaksud dalam ayat (2), maka setelah lewat jangka waktu empat bulan sejak diterimanya permohonan. Badan atau pejabat tata usaha negara yang bersangkutan dianggap telah mengeluarkan keputusan penolakan.

Beberapa ciri sengketa tata usaha negara, di antaranya adalah sebagai berikut:

\section{Para Pihak yang Bersengketa}

Jika melihat rumusan Pasal 1 angka 10 UU 51/2009 di atas, yang bersengketa adalah orang atau badan hukum perdata dengan badan atau pejabat tata usaha negara, baik di pusat maupun di daerah. Tergugat adalah badan atau pejabat tata usaha negara yang mengeluarkan keputusan berdasarkan wewenang yang ada padanya atau yang dilimpahkan kepadanya yang digugat oleh orang atau badan hukum perdata. Menurut Rozali Abdullah dalam bukunya Hukum Acara 
Peradilan Tata Usaha Negara (hal.5), Peradilan TUN hanya berwenang mengadili sengketa TUN, yaitu sengketa antara orang atau badan hukum perdata dengan badan atau pejabat tata usaha negara.

\section{Diselesaikan di Pengadilan Tata Usaha Negara}

Pengadilan adalah pengadilan tata usaha negara dan pengadilan tinggi tata usaha negara di lingkungan peradilan tata usaha negara.[2] Pengadilan bertugas dan berwenang memeriksa, memutus, dan menyelesaikan sengketa Tata Usaha Negara.[3]

\section{Keputusan Tata Usaha Negara sebagai Objek Sengketa}

Keputusan Tata Usaha Negara berdasarkan Pasal 1 angka 9 UU 51/2009 didefinisikan sebagai berikut:

Keputusan Tata Usaha Negara adalah suatu penetapan tertulis yang dikeluarkan oleh badan atau pejabat tata usaha negara yang berisi tindakan hukum tata usaha negara yang berdasarkan peraturan perundang-undangan yang berlaku, yang bersifat konkret, individual, dan final, yang menimbulkan akibat hukum bagi seseorang atau badan hukum perdata.

Menurut Yuslim dalam bukunya Hukum Acara Peradilan Tata Usaha Negara (hal. 47) bahwa rumusan Keputusan Tata Usaha Negara menurut Pasal 1 angka 9 UU 51/2009 mengandung unsur-unsur:

-penetapan tertulis,

-Badan atau Pejabat Tata Usaha Negara, -tindakan hukum tata usaha negara, 
-peraturan perundang-undangan yang berlaku,

-konkret,

-individual,

-final, dan

-akibat hukum bagi seseorang atau badan hukum perdata.

\section{Dengan Mengajukan Gugatan Tertulis}

Kita dapat pahami bahwa Sengketa Tata Usaha Negara diselesaikan di Pengadilan Tata Usaha Negara dengan mengajukan gugatan tertulis yang berisi tuntutan agar Keputusan Tata Usaha Negara yang disengketakan itu dinyatakan batal atau tidak sah, dengan atau tanpa disertai tuntutan ganti rugi dan/atau direhabilitasi. Alasan yang dapat digunakan dalam gugatan tertulis disebutkan dalam Pasal 53 ayat (2) UU 9/2004 sebagai berikut:

a. Keputusan Tata Usaha Negara yang digugat itu bertentangan dengan peraturan perundangundangan yang berlaku;

b. Keputusan Tata Usaha Negara yang digugat itu bertentangan dengan asas-asas umum pemerintahan yang baik.

\section{Terdapat Tenggang Waktu Mengajukan Gugatan}

Gugatan dapat diajukan hanya dalam tenggang waktu sembilan puluh hari terhitung sejak saat diterimanya atau diumumkannya Keputusan Badan atau Pejabat Tata Usaha Negara. Bagi pihak yang namanya tersebut dalam Keputusan Tata Usaha Negara yang digugat, maka tenggang waktu sembilan puluh hari itu dihitung sejak hari diterimanya Keputusan Tata Usaha Negara yang digugat. 
Dalam hal yang hendak digugat itu merupakan keputusan menurut ketentuan:

a. Pasal 3 ayat (2) UU 5/1986, tenggang waktu sembilan puluh hari itu di hitung setelah lewatnya tenggang waktu yang ditentukan dalam peraturan dasarnya, yang dihitung sejak tanggal diterimanya permohonan yang bersangkutan;

b. Pasal 3 ayat (3) UU 5/1986, maka tenggang waktu sembilan puluh hari itu dihitung setelah lewatnya batas waktu empat bulan yang dihitung sejak tanggal diterimanya permohonan yang bersangkutan.

Dalam hal peraturan dasarnya menentukan bahwa suatu keputusan itu harus diumumkan, maka tenggang waktu sembilan puluh hari itu dihitung sejak hari pengumuman tersebut.

\section{Asas Praduga Tak Bersalah}

Menurut Rozali Abdullah (hal. 6) bahwa di peradilan Tata Usaha Negara juga diberlakukan asas praduga tak bersalah (presumption of innocent) seperti yang kita kenal dalam hukum acara pidana. Di mana seorang pejabat Tata Usaha Negara tetap dianggap tidak bersalah di dalam membuat suatu Keputusan Tata Usaha Negara sebelum ada putusan hakim yang telah mempunyai kekuatan hukum tetap yang menyatakan ia salah di dalam membuat Keputusan Tata Usaha Negara atau dengan kata lain suatu Keputusan Tata Usaha Negara tetap dianggap sah (tidak melawan hukum), sebelum adanya putusan hakim yang telah mempunyai kekuatan hukum tetap yang menyatakan keputusan tersebut tidak sah (melawan hukum). Sehingga digugatnya suatu Keputusan Tata Usaha Negara, tidak akan menyebabkan tertundanya pelaksanaan keputusan tersebut. 


\section{Peradilan In Absentia}

Dalam Pasal 72 UU 5/1986 dijelaskan mengenai peradilan in absentia atau sidang berlangung tanpa hadirnya tergugat. Selengkapnya berbunyi sebagai berikut:

1. Dalam hal tergugat atau kuasanya tidak hadir di persidangan dua kali sidang berturut-turut dan/atau tidak menanggapi gugatan tanpa alasan yang dapat dipertanggung jawabkan meskipun setiap kali telah dipanggil dengan patut, maka Hakim Ketua Sidang dengan Surat penetapan meminta atasan tergugat memerintahkan tergugat hadir dan/atau menanggapi gugatan.

2. Dalam hal setelah lewat dua bulan sesudah dikirimkan dengan Surat tercatat penetapan sebagaimana dimaksud dalam ayat (1) tidak diterima berita, baik dari atasan tergugat maupun dari tergugat, maka Hakim Ketua Sidang menetapkan hari sidang berikutnya dan pemeriksaan sengketa dilanjutkan menurut acara biasa, tanpa hadirnya tergugat.

3. Putusan terhadap pokok gugatan dapat dijatuhkan hanya setelah pemeriksaan mengenai segi pembuktiannya dilakukan secara tuntas.

\section{Pemeriksaan Perkara Dengan Acara Biasa, Acara Cepat, dan Acara Singkat}

Sebagaimana pernah dijelasakan dalam artikel Perbedaan Acara Biasa, Acara Cepat, dan Acara Singkat Pada Peradilan TUN, hukum acara formal TUN (hukum acara dalam arti sempit) berupa langkah-langkah atau tahapan yang terbagi atas: 


\section{a. Acara biasa}

Dalam pemeriksaan sengketa TUN dengan acara biasa, tahapan penanganan sengketa adalah:

-Prosedur dismisal, pemeriksaan administratif untuk menetapkan apakah suatu gugatan dapat diterima atau tidak dapat diterima.

-Pemeriksaan persiapan, pada tahap ini dimaksudkan untuk melengkapai gugatan yang kurang jelas.

-Pemeriksaan di sidang pengadilan

b. Acara cepat

pemeriksaan dengan acara cepat dilakukan apabila terdapat kepentingan penggugat yang cukup mendesak yang harus dapat disimpulkan dari alasan-alasan permohonannya.

c. Acara singkat

pemeriksaan dengan acara singkat dilakukan terhadap perlawanan. 


\section{PENUTUP}

Sehingga dari ketentuan tersebut maka dapat disimpulkan bahwa yang menjadi objek sengketa yaitu keputusan penolakan yang bersifat fiktif negatif, karena badan atau pejabat TUN tidak pernah mengeluarkan surat keputusan sehingga yang digugat bukan surat keputusan sebagaimana dimaksudkan dalam ketentuan Pasal 1 angka 9 UU PTUN.

\section{DAFTAR PUSTAKA}

Darmini Roza dan Laurensius Arliman S, Peran Pemerintah Daerah Di Dalam Melindungi Hak Anak Di Indonesia, Masalah-Masalah Hukum, Volume 47, Nomor 1, 2018. https://doi.org/10.14710/mmh.47.1.2018.10-21

Laurensius Arliman S, Peranan Metodologi Penelitian Hukum di Dalam Perkembangan Ilmu Hukum di Indonesia, Soumatera Law Review, Volume 1, Nomor 1, 201. http://doi.org/10.22216/soumlaw.v1i1.3346.

Laurensius Arliman S, Peran Badan Permusyawaratan Desa di Dalam Pembangunan Desa dan Pengawasan Keuangan Desa, Padjadjaran Journal of Law, Volume 4, Nomor 3, 2017. https://doi.org/10.15408/jch.v4i2.3433.

Laurensius Arliman S, Penanaman Modal Asing Di Sumatera Barat Berdasarkan UndangUndang Nomor 25 Tahun 2007 Tentang Penanaman Modal, Supremasi Hukum, Volume 1, Nomor 1, 2018. http://dx.doi.org/10.36441/hukum.v1i01.102 .

Laurensius Arliman S, Memperkuat Kearifan Lokal Untuk Menangkal Intoleransi Umat Beragama Di Indonesia, Ensiklopedia of Journal, Volume 1, Nomor 1, 2018, https://doi.org/10.33559/eoj.v1i1.18.

Laurensius Arliman S, Perkawinan Antar Negara Di Indonesia Berdasarkan Hukum Perdata Internasional, Kertha Patrika, Volume 39, Nomor 3, 2017 , https://doi.org/10.24843/KP.2017.v39.i03.p03.

Laurensius Arliman S, Partisipasi Masyarakat Di Dalam Pengelolaan Uang Desa PascaUndangUndang Nomor 6 Tahun 2014 Tentang Desa, Jurnal Arena Hukum, Volume 12, Nomor 2, 2019, https://doi.org/10.21776/ub.arenahukum.2019.01202.5. 
Laurensius Arliman S, Mewujudkan Penegakan Hukum Yang Baik Di Negara Hukum Indonesia, Dialogica Jurnalica, Volume 11, Nomor 1, 2019, https://doi.org/10.28932/di.v11i1.1831.

Laurensius Arliman S, Mediasi Melalui Pendekatan Mufakat Sebagai Lembaga Alternatif Penyelesaian Sengketa Untuk Mendukung Pembangunan Ekonomi Nasional, UIR Law Review, Volume 2, Nomor 2, 2018, https://doi.org/10.25299/uirlrev.2018.vol2(02).1587

Laurensius Arliman S, Peranan Filsafat Hukum Dalam Perlindungan Hak Anak Yang Berkelanjutan Sebagai Bagian Dari Hak Asasi Manusia, Doctrinal, Volume 1, Nomor 2,2016.

Laurensius Arliman S, Ni Putu Eka Dewi, Protection of Children and Women's Rights in Indonesiathrough International Regulation Ratification, Journal of Innovation, Creativity and Change Volume 15, Nomor 6, 2021.

Laurensius Arliman S, Gagalnya Perlindungan Anak Sebagai Salah Satu Bagian Dari Hak Asasi Manusia Oleh Orang Tua Ditinjau Dari Mazhab Utilitarianisme, Jurnal Yuridis, Volume 3, Nomor 2, 2016, http://dx.doi.org/10.35586/.v3i2.180.

Laurensius Arliman S, Tantangan Pendidikan Kewarganegaraan Pada Revolusi 4.0, Jurnal Ensiklopedia Sosial Review, Volume 2, Nomor 3, $2020 .$. 